\title{
SISTEM INFORMASI MONITORING PERKEMBANGAN PROYEK BERBASIS WEB PADA PT. WAHANA REKA TEKINDO, JAKARTA
}

\author{
Moh Ikhsan Saputro \\ Program Studi Sistem Informasi \\ Univeristas Mohammad Husni \\ Thamrin Jakarta \\ J1. Raya Pd. Gede No. 23-25, Jakarta, \\ Indonesia \\ Emailm.ikhsan68i@gmail.com
}

\author{
Toni Sukendar \\ Program Studi Manajemen Informatika \\ AMIK BSI Jakarta \\ J1. RS Fatmawati No.24 Jakarta, \\ Indonesia \\ Email : toni.tns@bsi.ac.id
}

\author{
Aziz Setyawan H \\ Program Studi Teknik Komputer \\ AMIK BSI Tegal \\ Jl. Sipelem No.22 Tegal Barat - Tegal - \\ Jawa Tengah 52112 \\ email : aziz.aiz@,bsi.ac.id
}

\begin{abstract}
Abstrak - PT. Wahana Reka Tekindo, Jakarta adalah perusahaan yang bergerak pada bidang penyediaan jasa konsultansi yang mencakup dua sub bidang jasa usaha antara lain jasa konsultansi bidang konstruksi dan non konstruksi. Sebagai perusahaan yang berkaitan dengan pelaksanaan proyek, maka perlu adanya pemantauan dan pengawasan terhadap perkembangan proyek. Seiring dengan perkembangan dunia teknologi dan informasi dewasa ini yang telah mengalami kemajuan yang sangat pesat sehingga memunculkan gagasan untuk pemanfaatannya untuk membantu Manager dan project officer terkait pengelolaan proyek serta dapat menjalankan fungsi manajerial perusahaan dengan baik seperti fungsi monitoring dan evaluasi pada proyek-proyek yang dijalankan. Sistem Informasi yang terintegrasi dengan baik akan memudahkan dan mempercepat penyampaian informasi kepada pemilik proyek. Sistem monitoring proyek ini menggunakan metode waterfall model yang paling umum digunakan. Pembuatan aplikasi berbasis website pemrogramannya menggunakan HTML, CSS dan PHP dengan MYSQL digunakan sebagai database servernya. Hasil dari penelitian ini adalah sebuah sistem informasi monitoring dalam sebuah website yang menampilkan informasi perkembangan proyek dari mulai terkontrak hingga proyek selesai.
\end{abstract}

Keywords: Information system, website, monitoring and evaluation of Project.

\section{PENDAHULUAN}

Dalam era globalisasi saat ini, Peranan teknologi informasi khususnya teknologi internet mempermudah dan membantu berbagai bidang pekerjaan yang terkait dengan kemudahan akses, jarak dan waktu. Semakin mudahnya akses internet pada masa sekarang turut mendorong berbagai pelaku bisnis baik dikalangan pemerintah maupun swasta berlomba untuk memanfaatkannya.

PT. Wahana Reka Tekindo, Jakarta, merupakan perusahaan yang bergerak di bidang jasa konsultansi, dengan mencakup dua bidang jasa usaha yaitu bidang jasa konsultansi konstruksi dan non konstruksi. Pada umumnya proyek yang dikerjakan oleh perusahaan ini bersumber dari pemerintah ataupun swasta dengan cara mengikuti proses lelang umum, di website tertentu dimulai dari proses pendaftaran hingga penunjukan pemenang dan keluarnya surat perjanjian kerja (kontrak/SPK) antara pemilik pekerjaan (Owner/PPK) dengan perusahaan.

Dalam lingkup internal perusahaan, pada prakteknya perusahaan terkendala dalam hal operasional proyek seperti halnya seorang manager proyek mempunyai tanggung jawab untuk mengawasi lebih dari satu kegiatan, mulai dari proses pra-lelang sampai dengan serah terima kegiatan kepada pemilik pekerjaan (owner)dalam melakukan tugasnya, seorang manajer proyek dibatasi oleh kemampuannya terutama dalam hal ketersediaan waktu untuk memantau (monitoring) pelaksanaan kegiatan setiap hari. hal tersebut dapat membuat kegiatan pemantauan dan koordinasi dalam proyek tidak berjalan maksimal.koordinasi yang baik sangat diperlukan untuk kesinambungan dan komunikasi antar pihak yang terlibat dalam suatu proyek. Oleh karena itu pada masa sekarang ini, dunia teknologi informasi dapat membantu dan memberi kemudahan seorang manajer proyek untuk melakukan pemantauan dan pengawasan suatu kegiatan dalam lingkungannya.

Meskipun manager dibantu oleh project officer yang juga bertanggung jawab terhadap operasional lapangan pada lebih dari satu proyek, seperti proses penjadwalan kegiatan proyek, penggajian tim tenaga ahli / pelaksana proyek, penagihan( invoice) ,penyampaian laporan / progres kegiatan, penyampaian laporan keuangan proyek. Dengan mengacu kepada tanggung jawab project officer yang sandingkan dengan kondisi sebenarnya permasalahan dan perkembangan dalam pengerjaan proyek tidak dapat diketahui dengan cepat mengakibatkan data dan informasi yang dibutuhkan kurang tepat waktu dan akurat / tidak sesuai dengan data perkembangan proyek yang ada. 
Untuk mengatasi permasalahan tersebut perlu adanya sebuah sistem sistem informasi dan basis data yang terintegrasi dan terstruktur dengan baik, seperti halnya sistem informasi berbasis website yang dinamis dan aman. Dengan sistem informasi berbasis website pihak yang berkepentingan dalam perusahaan dapat memperoleh informasi lebih cepat sehingga pengerjaan proyek dapat diselesaikan sesuai target dan diharapkan sistem informasi berbasis website ini dapat membantu seorang pimpinan dalam mengambil keputusan terhadap proyek yang dijalankan oleh PT. Wahana Reka Tekindo, jakarta.

\section{LANDASAN TEORI}

\section{A. Sistem}

Menurut Yasin (2012:260) "Sistem adalah suatu jaringan kerja dari prosedur-prosedur yang saling berhubungan, berkumpul bersama-sama untuk melakukan suatu kegiatan atau menyelesaikan suatu sasaran tertentu".

\section{B. Informasi}

Menurut Sibero (2011:10) menyimpulkan bahwa:

Informasi adalah sekumpulan data yang memiliki maksud dan tujuan serta dapat memberikan keterangan akurat yang diperlukan dalam pengambilan keputusan. Ditinjau dari sisi komputer, informasi adalah suatu hasil pengolahan data dari sistem komputer yang dibutuhkan pengguna yang memiliki manfaat bagi penggunanya. Hasil pengolahan dari kumpulankumpulan informasi yang saling terkait antara satu dan lainnya disebut sebagai Sistem Informasi

\section{Monitoring.}

proses pengumpulan dan analisis informasi berdasarkan indikator yang ditetapkan secara sistematis dan kontinu tentang kegiatan program sehingga dapat dilakukan tindakan koreksi untuk penyempurnaan program kegiatan itu selanjutnya. pemantauan yang dapat dijelaskan sebagai kesadaran (awareness) tentang apa yang ingin diketahui, pemantauan berkadar tingkat tinggi dilakukan agar dapat membuat pengukuran melalui waktu yang menunjukkan pergerakan ke arah tujuan atau menjauh dari itu. (Mardiani, Gentisya Tri: 2013).

\section{Proyek.}

Definisi proyek dapat diartikan gabungan dari sumbersumber daya seperti manusia, material, peralatan dan modal/biaya yang dihimpun dalam suatu wadah organisasi sementara untuk mencapai sasaran dan tujuan. Proyek adalah usaha sementara yang dilakukan untuk membuat produk atau jasa yang unik. Sementara berarti bahwa setiap proyek memiliki akhir yang pasti. Unik berarti bahwa produk atau jasa adalah memiliki perbedaan dalam beberapa hal yang khusus dibandingkan dengan produk atau jasa yang sejenis. Proyek harus diselesaikan dalam jangka waktu terbatas sesuai dengan kesepakatan. (Nugroho, Yuliandri Priyo: 2012).

Sebuah sistem informasi manajemen proyek (Project management information system) mengacu pada sistem otomatis atau perangkat lunak komputer yang digunakan oleh
Project Managemen Tim sebagai alat untuk pelaksanaan kegiatan yang tercantum dalam rencana Project Managemen.

(Badiru, 2008: Chap. 1).

Sumber: (Badiru,2008:Chap. 1)

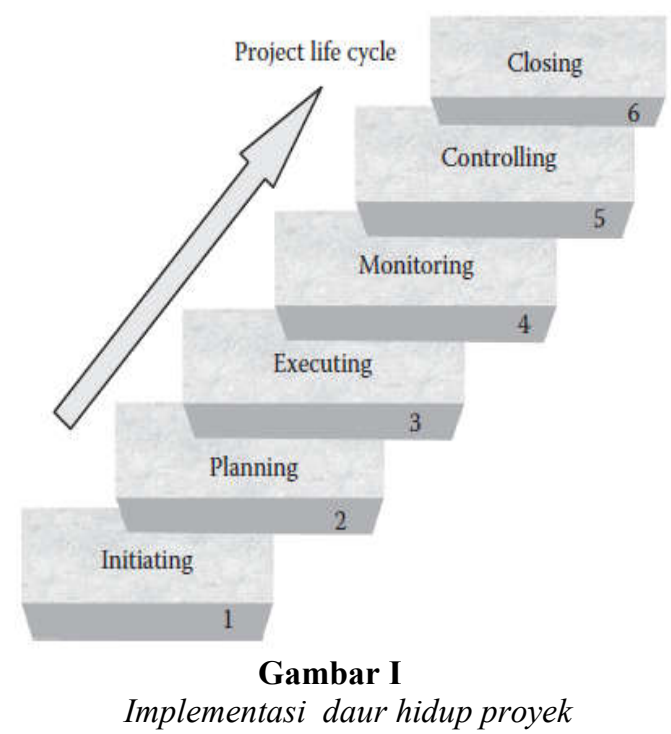

\section{METODE PENELITIAN}

Metode yang diambil dalam Perancangan Sistem Informasi Ini adalah Sebagai Berikut:

\section{A. Observasi.}

Metode observasi adalah peroses pencatatan pola perilaku subyek (orang), objek (benda) atau kejadian yang sistematik tanpa adanya pertanyaan atau komunikasi dengan individu-individu yang diteliti. Dengan metode ini penulis datang dan melakukan pengamatan langsung terhadap proses berjalannya sistem, subjek dan objek penelitian mengenai prilaku tata kelola kerja karyawan dan sistem kerja yang berjalan

\section{B. Wawancara}

Metode wawancara adalah proses memperoleh keterangan untuk tujuan penelitian dengan cara tanya jawab sambil bertatap muka antara pewawancara dengan responden untuk mendapatkan data dan informasi yang diharapkan.

\section{Studi Pustaka}

Studi pustaka adalah teknik pengumpulan data dengan melakukan penelaahan terhadap buku, kajian teoritis, referensi serta literatur serta berbagai laporan lainnya yang berkaitan dengan masalah. Setelah tahapan melakukan metode penelitian dengan observasi dan wawancara metode studi pustaka ini penting dilakukan untuk mendukung data yang telah didapat dari hasil observasi dengan referensi dari buku-buku, jurnal ebook yang mengacu / berhubungan pada bidang dan bahasan yang berkaitan dengan penyusunan skripsi ini. 
Metode Pengembangan Perangkat Lunak

Menurut Rosa dan Salahuddin (2013:28) mengemukakakan bahwa:Model SDLC air terjun (waterfall) sering juga disebut model sekuential linier (sequential linear) atau alur hidup klasik (classic life cycle). Model air terjun menyediakan pendekatan alur hidup perangkat lunak ssecara sekuensial atau terurut dimulai dari analisis, desain, pengujian, dan tahp pendukung (support).

Berikut adalah gambar air terjun:

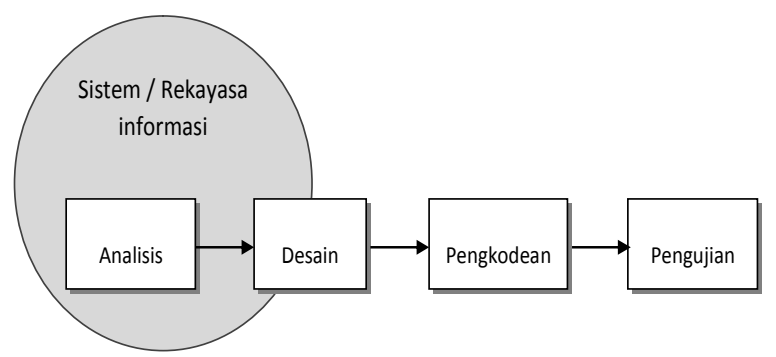

Sumber: Rosa dan Salahuddin ( 2013:28)

Gambar II

Waterfall Model

\section{HASIL DAN PEMBAHASAN}

\section{A. Proses Bisnis}

Proses bisnis sistem yang berjalan pada PT. Wahana Reka Tekindo, jakarta, dalam langkah awal pengelolaan suatu proyek dimulai pada saat pimpinan perusahaan (direktur/direktur utama) menyerahkan kontrak kerja (spk) kepada project officer, kemudianproject officer akan menyusun berkas perencanaan proyek mencakup (jadwal pelaksanaan kegiatan, jadwal penyerahan laporan dan jadwal pencairan / invoice) dan mengajukan berkas rencana anggaran biaya untuk biaya operasional proyek mencakup(biaya lansung personil, dan biaya langsung non personil), yang nantinya berkas akan diteruskan kepada manajeruntuk dilakukan analisa, jika kiranya ada kesalahan maka, akan dikembalikan kepada project officer untuk diperbaiki, namun jika tidak ada kesalahan maka berkas di teruskan ke pimpinan perusahaanuntuk di setujui.,kemudian di serahkan kembali kepada project officer maka selanjutnya proyek dilaksanakan dan project officer lah yang bertanggung jawab penuh terkait pelaksanaan dan pengelolaan proyek tersebut dari awal hingga proyek selesai.

\section{Gambar III}

Activity Diagram sistem berjalan proses Awal pengelolaan proyek

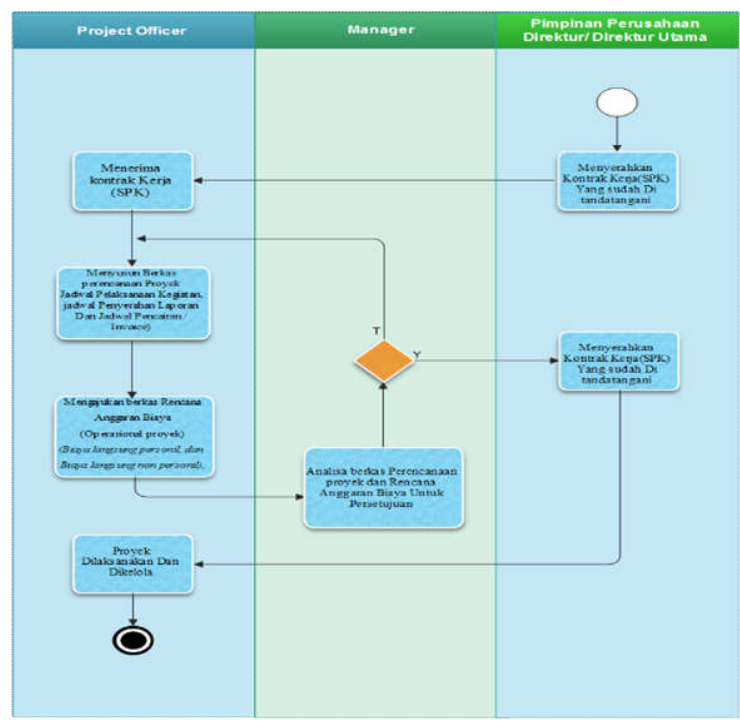

\section{B. Rancangan Sistem}

Sistem informasi monitoring perkembangan proyek berbasis web ini dibangun dengan maksud untuk memudahkan efektifitas dan efisiensi project manager dan project officer dalam bekerja .Tujuannya adalah memaksimalkan fungsi manajemen perusahaan dengan baik dalam hal mengontrol dan mengawasi suatu proyek yang sedang berjalan, Sehingga dapat menghasilkan data dan informasi yang baik, guna pengambilan keputusan dengan cepat. Seorang project manager diberikan tanggung jawab untuk mengelola beberapa proyek yang telah dimenangkan oleh perusahaan. Sementara project officer sebagai perpanjangan tangan dari project manager yang juga ikut bertugas dan bertanggung jawab untuk memastikan suatu proyek berjalan dengan baik. Dalam mengelola proyek yang telah ditugaskan kepadanya, seorang Project Manager dan project officer dapat memantaunya melalui menu proyek dihalaman depan website perusahaan. berikut ini spesifikasi kebutuhan dari sistem informasi monitoring perkembangan proyek.

\section{1) Use Case Diagram Halaman Project Officer/User}

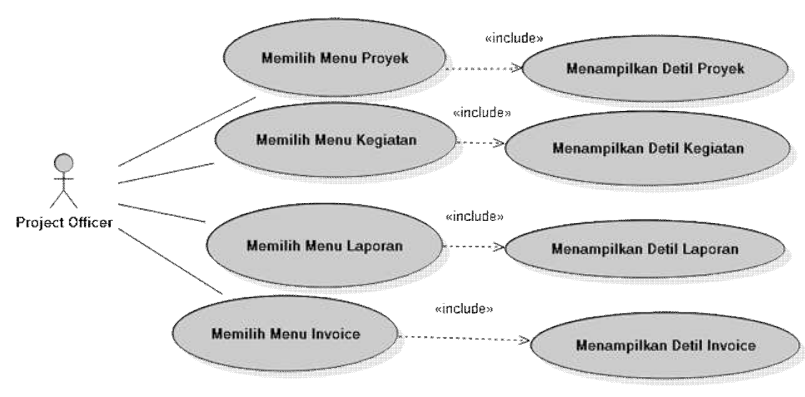

Gambar IV

Use Case Diagram Halaman Project Officer/User

Tabel I 
Deskripsi Use Case Diagram Halaman Project Officer/User

\begin{tabular}{|c|c|}
\hline Use Case Name & Project Officer/User \\
\hline Requirements & $\mathrm{A} 1, \mathrm{~A} 2, \mathrm{~A} 3, \mathrm{~A} 4$ \\
\hline Goal & $\begin{array}{l}\text { Project Officer/User dapat melihat halaman } \\
\text { beranda }\end{array}$ \\
\hline Pre-condition & Project Officer/User \\
\hline Post-condition & Project Officer/User \\
\hline Failed end condition & - \\
\hline Primary Actors & Project Officer/User \\
\hline Main Flow / Basic Path & $\begin{array}{l}\text { 1. Project Officer/User dapat melihat } \\
\text { halaman dashboard yang berisi } \\
\text { rangkuman progress proyek yang telah } \\
\text { didapat tahun ini. } \\
\text { 2. Project Officer/User dapat melihat } \\
\text { rangkuman progress kegiatan. } \\
\text { 3. Project Officer/User dapat melihat } \\
\text { rangkuman progress laporan. } \\
\text { 4. Project Officer/User dapat melihat } \\
\text { rangkuman progress invoice. }\end{array}$ \\
\hline Invariant & - \\
\hline
\end{tabular}

\section{2) Use Case Diagram Halaman Project Manager}

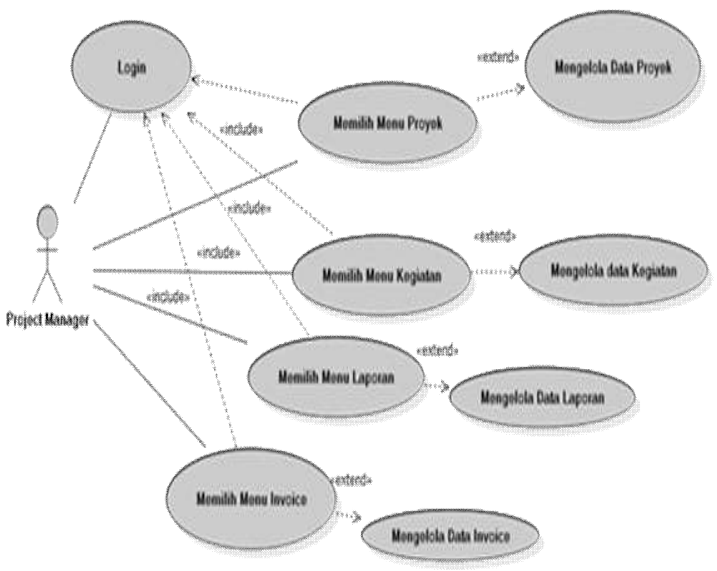

\begin{tabular}{|c|c|}
\hline Use Case Name & Project Manager \\
\hline Requirements & $\mathrm{B} 1, \mathrm{~B} 2, \mathrm{~B} 3, \mathrm{~B} 4, \mathrm{~B} 5$ \\
\hline Goal & $\begin{array}{l}\text { Project Manager dapat menambah, mengedit } \\
\text { dan menghapus data Proyek, laporan, kegiatan, } \\
\text { invoice. }\end{array}$ \\
\hline Pre-condition & $\begin{array}{l}\text { Project Manager Proyek, laporan, kegiatan, } \\
\text { invoice, proyek telah login }\end{array}$ \\
\hline Post-condition & Data tersimpan, terupdate atau terhapus \\
\hline Failed end condition & $\begin{array}{l}\text { Gagal menyimpan, mengupdate atau } \\
\text { menghapus }\end{array}$ \\
\hline Primary Actors & Project Manager \\
\hline Main Flow / Basic Path & $\begin{array}{l}\text { 1. Project Manager mengelola data proyek } \\
\text { 2. Project Manager mengelola data Kegiatan. } \\
\text { 3. Project Manager mengelola data Laporan } \\
\text { 4. Project Manager mengelola data Invoice. }\end{array}$ \\
\hline Invariant $\mathrm{A}$ & $\begin{array}{l}\text { (A1,A2,A3,A4,A5 ) Membuat, Melihat, } \\
\text { Merubah/Update ,Menghapus, Mencetak Data } \\
\text { Dan Melakukan Pencarian.(Nama Proyek/ID } \\
\text { user) }\end{array}$ \\
\hline
\end{tabular}

Gambar V

Use Case Diagram Halaman Project Manager

Tabel II

Deskripsi Use Case Diagram Halaman Project Manager

3) Use Case Diagram Administrator

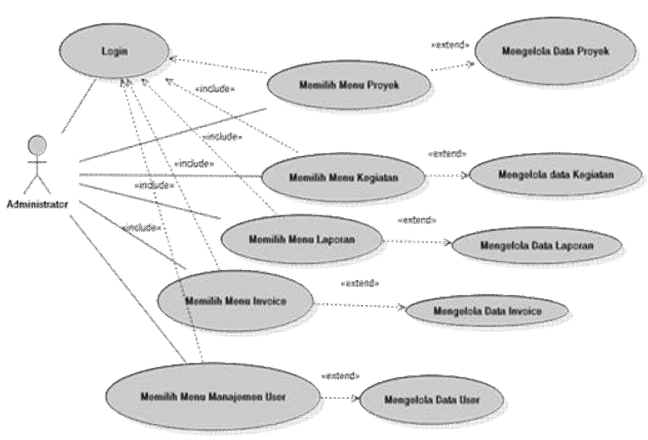

Gambar VI

Use Case Diagram Halaman Administrator

Tabel III

Deskripsi Use Case Diagram Halaman Administrator

\begin{tabular}{|c|c|}
\hline Use Case Name & Administrator \\
\hline Requirements & $\mathrm{C} 1, \mathrm{C} 2, \mathrm{C} 3, \mathrm{C} 4, \mathrm{C} 5$ \\
\hline Goal & $\begin{array}{l}\text { Admin dapat menambah, mengedit dan } \\
\text { menghapus data Proyek, laporan, kegiatan, } \\
\text { invoice, User. }\end{array}$ \\
\hline Pre-condition & $\begin{array}{l}\text { Admin Proyek, laporan, kegiatan, invoice, } \\
\text { proyek telah login }\end{array}$ \\
\hline Post-condition & Data tersimpan, terupdate atau terhapus \\
\hline Failed end condition & $\begin{array}{l}\text { Gagal menyimpan, mengupdate atau } \\
\text { menghapus }\end{array}$ \\
\hline Primary Actors & Administrator \\
\hline
\end{tabular}

\begin{tabular}{|l|l|}
\hline Main Flow / Basic Path & 1. Administrator mengelola data proyek \\
& 2. Administrator mengelola data Kegiatan. \\
3. Administratror mengelola data Laporan \\
4. Administrator mengelola data Invoice. \\
5. Administrator mengelola data User \\
(A1,A2,A3,A4,A5) Membuat, Melihat, \\
Merubah/Update,Menghapus, Mencetak Data \\
Dan Melakukan Pencarian.(Nama Proyek/ID \\
user)
\end{tabular}


4) Usecase Diagram mengelola data proyek

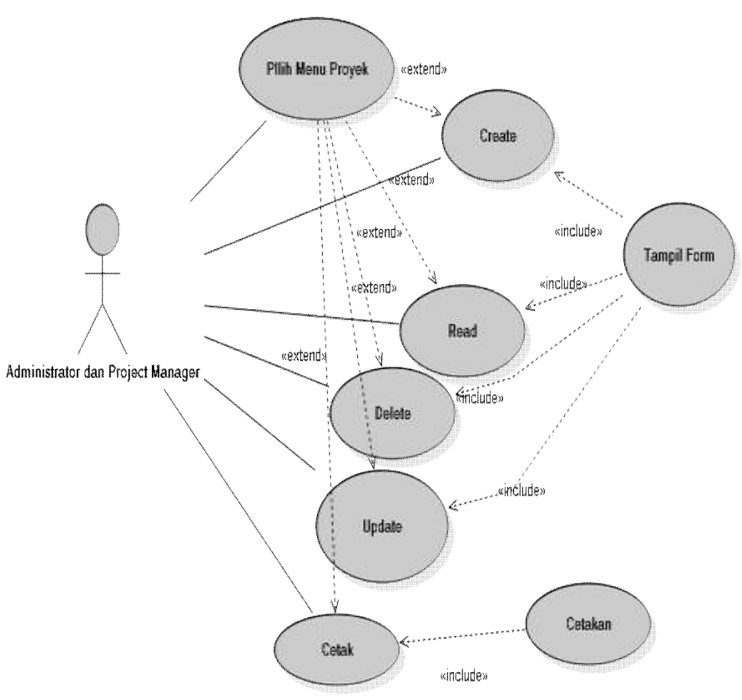

\section{Gambar VII}

Usecase Diagram mengelola data proyek

5) Usecase Diagram mengelola data kegiatan

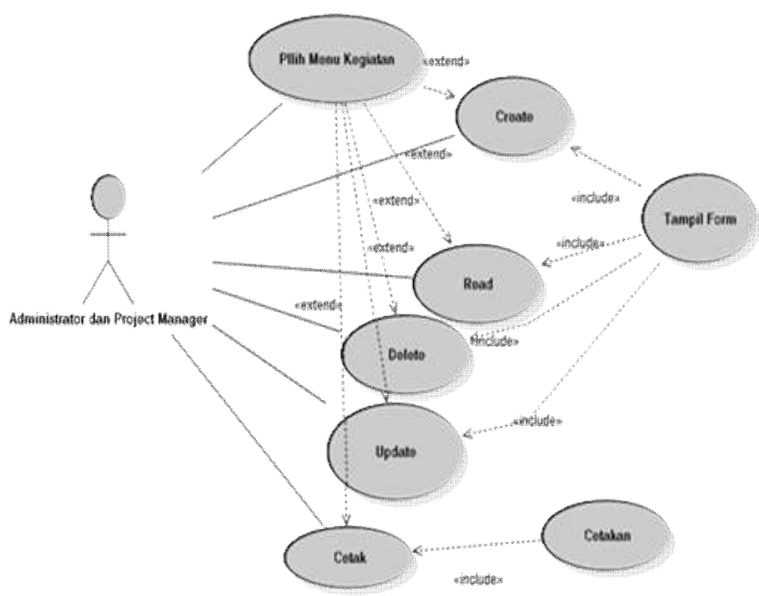

Gambar VIII

Usecase Diagram mengelola data kegiatan

6) Usecase Diagram mengelola data laporan

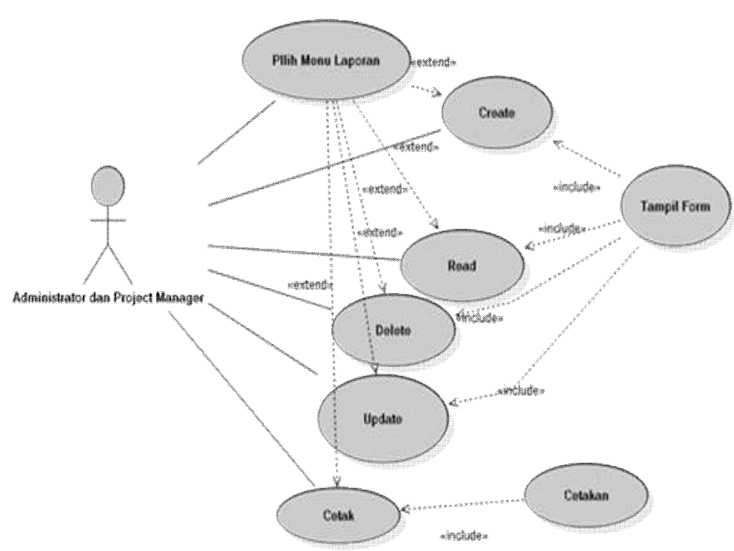

Gambar IX

Usecase Diagram mengelola data Laporan

7) Usecase Diagram mengelola data invoice

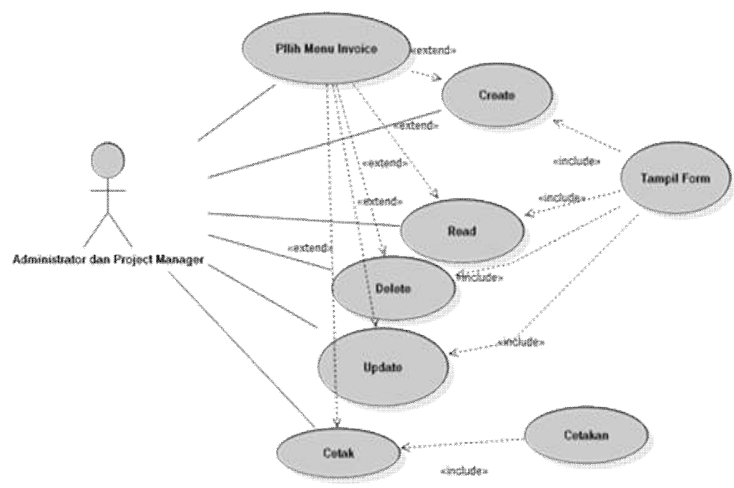

Gambar X

Usecase Diagram mengelola data invoice

8) Activity Diagram Halaman User/ Project Officer 


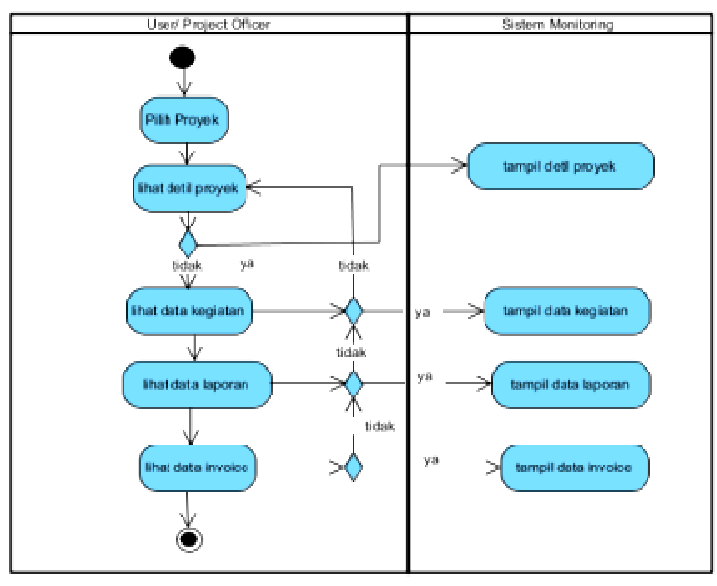

GambarXI

Activity Diagram Halaman User/Project Officer

9) Activity Diagram Halaman Project Manager

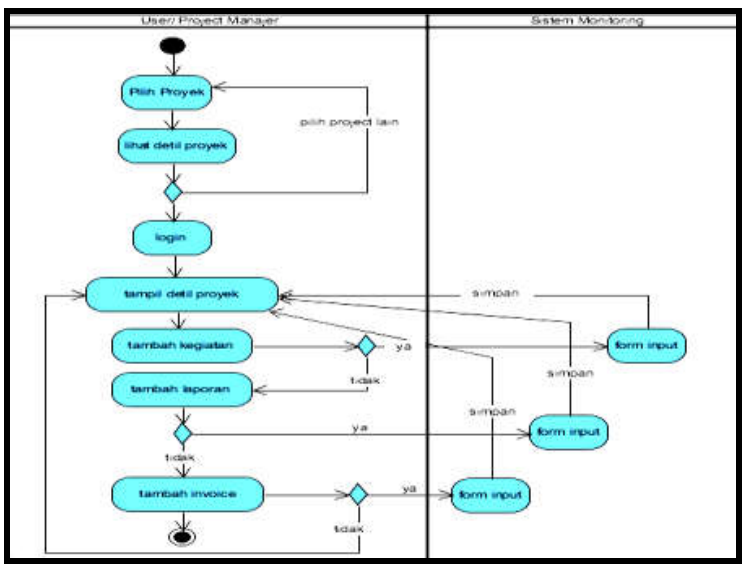

Gambar XII

Activity Diagram Halaman Project Manager

10) Activity Diagram Halaman Administrator

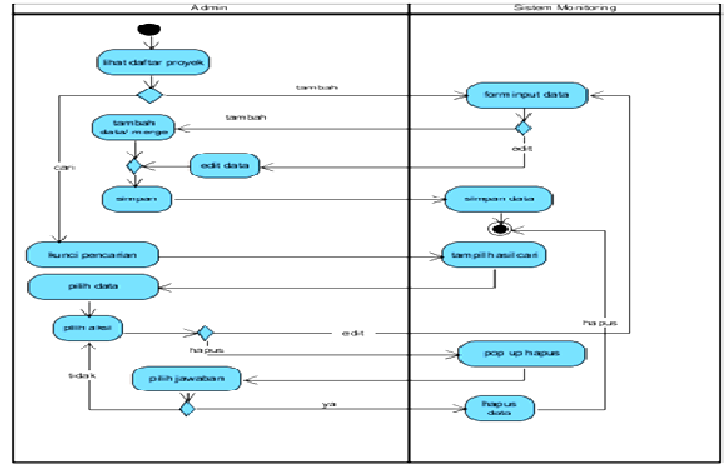

Gambar XIII

Activity Diagram Halaman Administrator
1) Logical Data Model

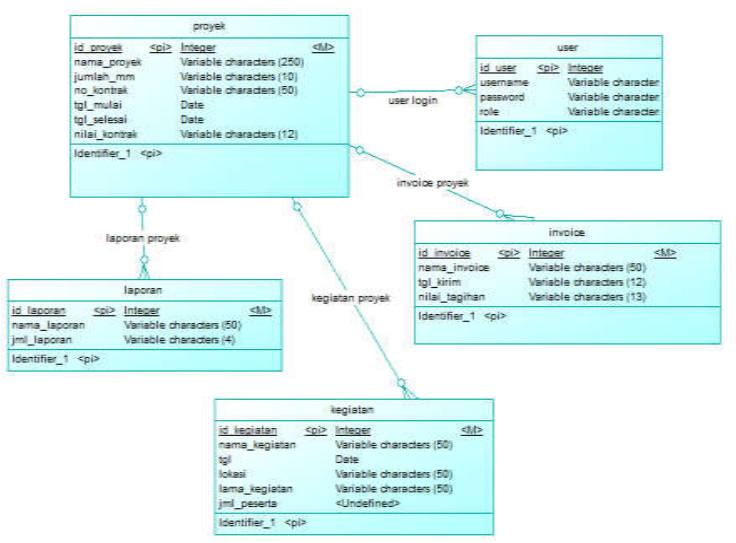

Gambar XIV

Logical Data Model SIMPP

2) Physical Data Model

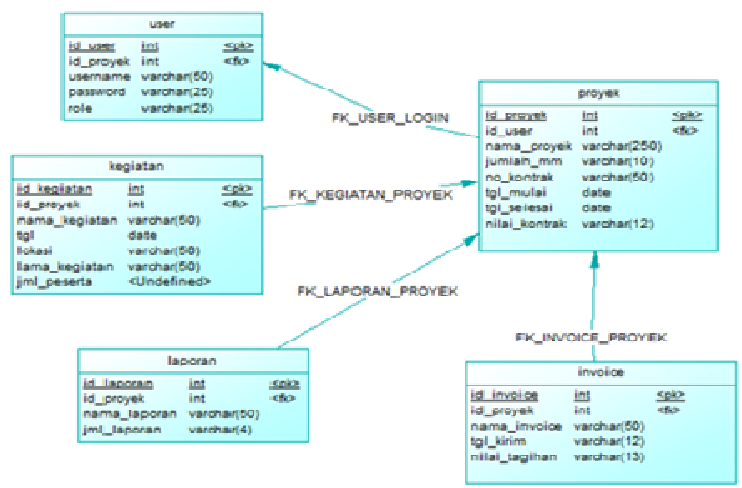

Gambar XV

Physical Data Model SIMPP

\section{Class Diagram}

Berikut ini adalah objek-objek yang teridentifikasi :

1. Proyek

2. Kegiatan

3. Laporan

4. Invoice

\section{DataBase}




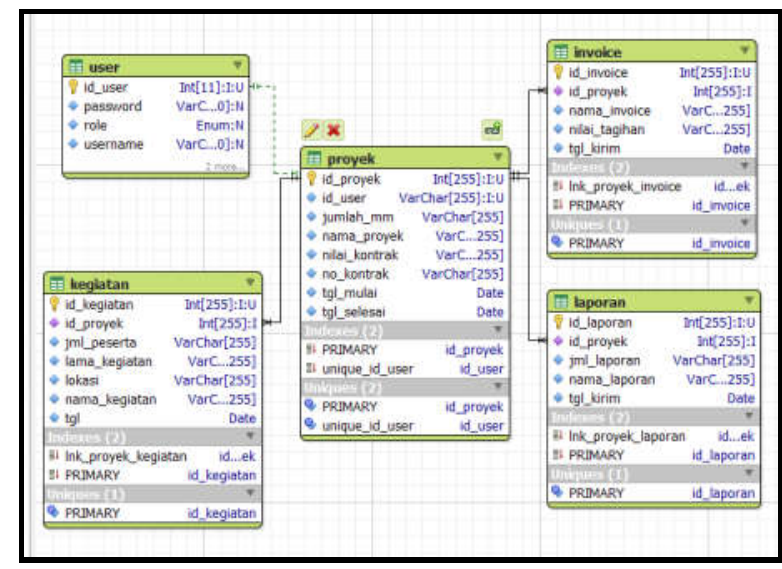

Gambar XVI

Class Diagram SIMPP

5. User Interface

A. Tampilan Halaman Beranda

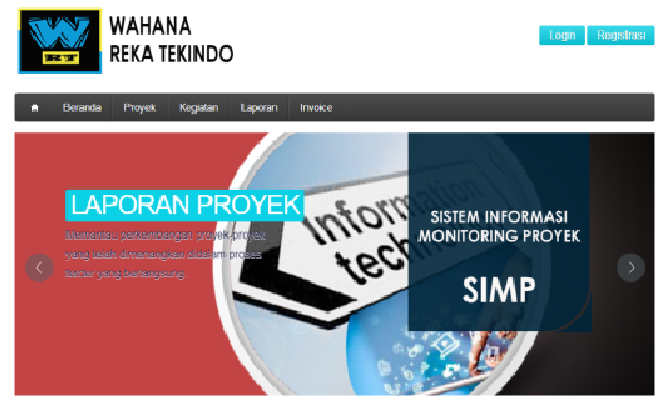

Gambar XVII

Halaman Beranda

B. Tampilan Halaman Login

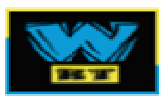

Sistem Informasi Monitoring Proyek

Login Administrator

\begin{tabular}{l} 
Username \\
admin| \\
Password \\
\hline$\ldots . . .$. \\
\hline \multicolumn{2}{|c|}{} \\
\hline
\end{tabular}

Gambar XVIII

Halaman Login

\section{Tampilan Halaman Administrator}

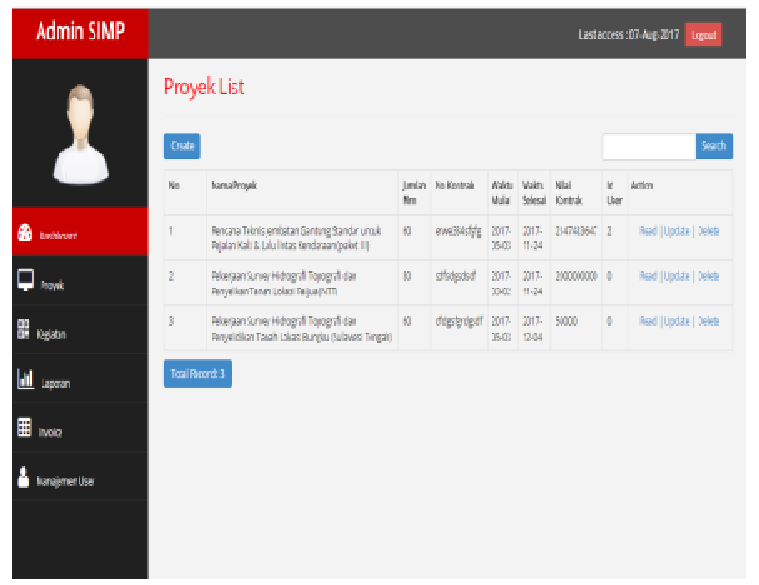

Gambar XIX

Tampilan Halaman Admin-Proyek

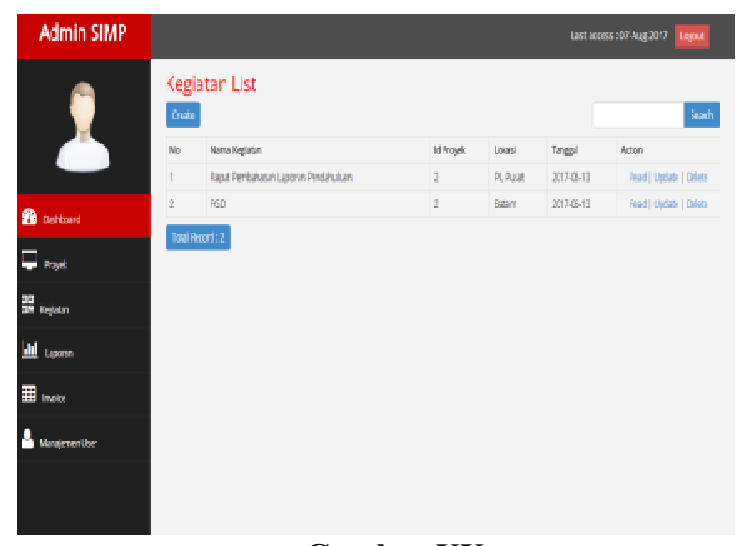

Gambar XX

Tampilan Halaman Admin -Kegiatan

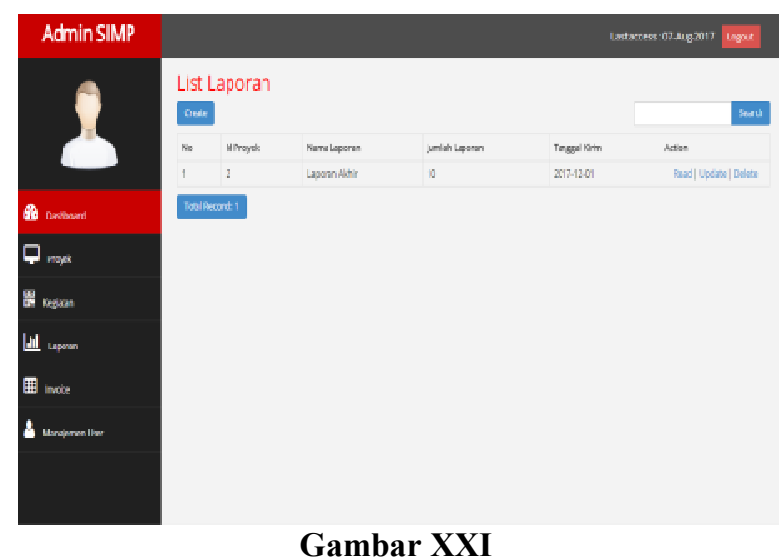

Tampilan Halaman Admin-Laporan 


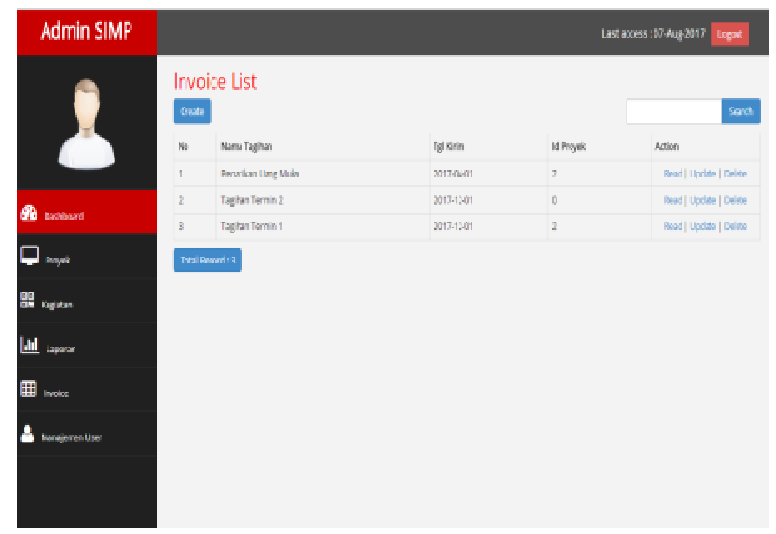

Gambar XXII

Tampilan Halaman Admin-Invoice

\section{Kesimpulan}

Setelah melakukan analisis terhadap permasalahan mengenai manajemen Pengelolaan Proyek yang ada pada PT. Wahana Reka Tekindo, jakarta, penulis mencoba memberikan alternatif solusi dengan membuat sistem informasi monitoring Perkembangan Proyek berbasis web secara online, maka dengan adanya sistem informasi ini diharapkan menjadi kerangka dasar dalam hal manajemen pengelolaan proyek di dalam perusahaan yang untuk kedepannya dimaksudkan sebagai bahan solusi terhadap permasalahan-permasalahan yang dihadapi guna menjadikan dasar pengambilan keputusan pimpinan perusahaan pada suatu kasus yang dihadapi.

Oleh karena itu kesimpulan dari pembangunan sistem informasi monitoring perkembangan proyek berbasis web ini adalah:

1. Dengan adanya sistem informasi monitoring perkembangan proyek berbasis web secara online manajemen perusahaan dapat menjadikannya sebagai database dan sumber informasi keproyekan.

2. Meningkatkan eksistensi dan efektivitas media penyimpanan data dan informasi karena website dapat di akses di manapun dan kapanpun.

3. Terbangunnya suatu sistem manajemen pengelolaan proyek yang tertata dan terdistribusi.

4. Sistem informasi ini dibuat secara online yang dibuat dapat mempercepat proses pengolahan data dan informasi seperti menyimpan, mengedit, menghapus data proyek dan lainnya serta pembuatan laporan yang cepat efisien.

5. Diharapkan dengan terbangunnya sistem informasi ini manajemen perusahaan dapat lebih terencana terkait pengelolaan proyek, mengenai Rencana anggaran, administrasi, laporan dan resiko.

\section{Saran}

Berdasarkan pembahasan serta kesimpulan diatas, maka penulis bermaksud memberikan saran agar kedepannya berjalan lebih baik.

Adapun saran-saran yang dapat penulis sampaikan adalah sebagai berikut :
1. Melakukan Pelatihan bagi pengguna sistem informasi monitoring perkembangan proyek berbasis web ini agar terhindar dari kesalahan proses masukan dan keluaran sistem

2. Menambah database terkait keproyekan siring perkembangan kebutuhan perusahaan dimasa mendatang..

3. Penggunan sistem harus memperbaharui bahasa pemrograman, database dan server agar sistem tidak usang

4. Dari tampilan website yang sudah ada diharapkan melakukan perubahan atau menambah menu-menu agar lebih menarik.

5. Melakukan perawatan hardware dan software secara berkala menghindari hal-hal yang tidak diinginkan, seperti serangan virus atau serangan dari luar (hacking).

\section{Daftar Pustaka}

Aprisa., dan Siti Monalisa. (2015). Jurnal Rekayasa dan Manajemen Sistem Informasi. Riau:Vol. 1, No. 1.:49-54.

Amsler, G. M., Findley, H. M dan Ingram, E. (2009). Performance Monitoring: Guidance for the Modern Workplace. Supervision.

Anhar. (2010). Panduan menguasai PHP \&Mysql secara otodidak. Jakarta: Media Kita.

Badiru, Adedeji B. (2008). Step Project Management.Guide For Science, Technology, and Engineering Project.

Hidayat, Rahmat. (2010). Cara praktis membangun website gratis. Jakarta : PT.Elex Media Komputindo.

Kadir, Abdul. (2008). Dasar Pemrograman Web Dinamis Menggunakan PHP. Yogyakarta : Andi.

Kusrini. (2007). Konsep dan Aplikasi Sistem Pendukung Keputusan. Yogyakarta :Andi.

.S.A Rosa., dan M. Shalahuddin. (2013). Modul Pembelajaran Rekayasa Perangkat

Lunak (Terstruktur dan Berorientasi Objek). Bandung: Modula. 
